\title{
O sorteio na política: como os minipúblicos vêm transformando a democracia
}

\author{
$\overline{\text { André Rubião }{ }^{1}(\mathbb{D})}$
}

\begin{abstract}
Este artigo analisa o uso do sorteio na política sob uma perspectiva genealógica e contemporânea. Ele reflete em torno desse mecanismo, pouco conhecido na América Latina, que seleciona cidadãos aleatoriamente para tomar decisões. O artigo expõe como essa ideia surgiu na Grécia antiga, depois foi utilizada na Itália renascentista, até ser rejeitada pelas repúblicas modernas. Ele mostra o resgate do sorteio nos anos 1970, em meio aos debates sobre a crise da representação e à ascensão da democracia deliberativa, trazendo como novidade o uso da amostra representativa, tal como ocorre nos júris de cidadãos, nas células de planificação e nas pesquisas deliberativas. O artigo revela a dinâmica em torno desses minipúblicos e o campo de experimentação que se abriu a partir deles. Analisam-se as críticas que esses mecanismos vêm recebendo, em especial o ceticismo com relação ao saber-cidadão e o fato de eles impossibilitarem a participação espontânea da sociedade. São apresentados exemplos recentes, como o orçamento participativo berlinense e a emenda constitucional irlandesa, que fornecem uma base empírica não somente para se contrapor a esses argumentos, mas para mostrar que o sorteio vem se tornando uma alternativa viável na política.
\end{abstract}

Palavras-chave: sorteio; minipúblicos; democracia deliberativa; participação social; representação política

\section{Introdução}

O argumento de Aristóteles (1997, p. 139), em que associa a eleição com a oligarquia e o sorteio com a democracia, continua nos surpreendendo. A modernidade fez do voto popular o paroxismo do governo do povo e relegou as experiências com a seleção aleatória de cidadãos para exercer cargos públicos aos livros de história. Pouco a pouco, no entanto, essa realidade vem se transformando: das iniciativas precursoras de Dienel (1970) e Crosby (1975), passando pelas pesquisas deliberativas de Fishkin (1991) e pelas conferências de consenso no universo da ciência (Hendriks, 2005), até o processo de reforma eleitoral da Colúmbia Britânica no Canadá e as iniciativas de mudança constitucional na Islândia e na Irlanda, é possível estimar que cerca de mil experiências

\footnotetext{
${ }^{1}$ Faculdade de Direito Milton Campos - Núcleo de Estudos sobre Gestão de Políticas Públicas (Negesp), Nova Lima (MG), Brasil; IBS/FGV, Belo Horizonte (MG), Brasil. E-mail: <andrerubiao@hotmail.com>.
} 
envolvendo o sorteio foram realizadas nas últimas décadas (Vergne, 2009; Van Reybrouck, 2017).

Apesar disso, o tema continua sendo tratado de forma marginal. É verdade que nos últimos anos a seleção aleatória na política chegou a ser reivindicada por autores importantes - Burnheim (1985), Dahl (1989), Elster (1989), Goodwin (1992), Zizek (2004) etc. -, ocupando as mais variadas posições no espectro da filosofia política, mas na maior parte das vezes esse mecanismo segue sendo visto como algo exótico ou é simplesmente ignorado pelo universo acadêmico e pela população em geral. A espinha dorsal da ideia é muito simples: trata-se de constituir uma amostra representativa de pessoas sorteadas, ou seja, uma miniatura da sociedade, respeitando critérios de gênero, idade e classe social, e pedir para que esse grupo de cidadãos selecionados ao acaso deliberem sobre determinado tema de interesse público. A proposta, no entanto, sempre gerou desconfiança. As principais críticas ou desafios giram em torno de quatro pontos: i) os riscos de conceder o poder às pessoas comuns, sendo que elas podem ser despreparadas (Merkle, 1996); ii) a dificuldade de estabelecer regras de conduta e accountability, para evitar assimetrias e distorções (Parkinson, 2006); iii) a possibilidade de a adoção desses mecanismos excluir pessoas que queiram participar de forma espontânea, prejudicando a formação de uma identidade de grupo (Young, 2006) ou o desenvolvimento de contraesferas públicas (Fraser, 1990, 2009); iv) a dificuldade das iniciativas com sorteio de propor mudanças estruturais na política (Goodin e Dryzek, 2006; Pateman, 2012).

Essas observações são pertinentes e vêm estimulando o debate acadêmico ao redor do mundo. Tendo em vista esse cenário, o objetivo deste artigo é apresentar uma "revisão da literatura abrangente" (Yin, 2016)² sobre o uso do sorteio na política. A escolha desse método se justifica pelo fato de algumas iniciativas recentes envolvendo a seleção aleatória - como o orçamento participativo de Berlim, a reforma constitucional da Irlanda e as experiências a partir do grupo G1000 na Bélgica - terem contribuído para uma contraposição a parte das críticas que o mecanismo vinha recebendo. Trata-se, então, de expor um panorama geral e um estado da arte, com o intuito de trazer uma visão mais atualizada e abrangente sobre as controvérsias e as tendências em torno desse assunto. Além disso, numa perspectiva genealógica (Foucault, 1981), este artigo busca compreender e transformar a dinâmica por trás da marginalidade do sorteio na teoria democrática. No caso do Brasil, onde a literatura sobre o tema é escassa ${ }^{3}$ e as experiências

\footnotetext{
2 Segundo Yin (2016, p. 56), a "revisão da literatura abrangente" visa "reunir o que se conhece sobre um determinado tema, possivelmente sublinhando linhas de pensamento controversas ou díspares ou mesmo o progresso no decorrer do tempo no conhecimento acumulado sobre um assunto".

3 No que toca à literatura relevante sobre o tema, é possível identificar: i) um artigo de Miguel (2000), bastante consistente, mas publicado há quase duas décadas; ii) um artigo de Rubião (2013) e outro de Rubião e Anversa (2015), sendo o primeiro um verbete sintético e o segundo um relato sobre o uso do sorteio no orçamento participativo de Berlim; iii) um artigo de Quevedo, Ferreira e Invernizzi (2016), que traz uma proposta de uso de minipúblico para debater os riscos do uso de nanotecnologia; iv) a tese de doutorado de Baggia (2017), que dedica um capítulo à comparação entre os minipúblicos e as instituições participativas latino-americanas; v) um artigo de Sampaio (2012) sobre o uso de minipúblicos na deliberação online; vi) o livro de Fishkin (2015), traduzido para o português, que trata mais especificamente das
} 
são praticamente inéditas ${ }^{4}$, essa abordagem se justifica pelos seguintes fatores: i) ela pode abrir as portas para novas iniciativas com o sorteio, seja da forma como esse instrumento vem sendo utilizado no Norte ou conciliando-o com as instituições clássicas advindas do Sul; ii) ela revela que os experimentos mais recentes envolvendo a seleção aleatória diminuem a distância entre participação, mais ligada ao Sul, e deliberação, mais ligada ao Norte, contribuindo para nuançar algumas críticas que o mecanismo vem recebendo no Brasil; iii) ela traz um levantamento e uma atualização da terminologia que vem sendo utilizada em torno dessa temática, visando sedimentar o seu uso na literatura do país.

$\mathrm{O}$ artigo está dividido em seis partes. Na primeira seção, pretende-se apresentar a história desse instrumento; na segunda, mostra-se como ele foi resgatado depois de um longo eclipse; a seguir, nas terceira e quarta seções, faz-se um balanço reflexivo das principais iniciativas espalhadas pelo mundo; na quinta seção, mostram-se os principais desafios da seleção aleatória; e, por fim, analisa-se, numa perspectiva utópica, até onde essa ideia pode chegar.

Ao ilustrar o potencial do sorteio e o paradoxo do seu obscurantismo, Sintomer faz alusão ao famoso "método de Morelli" (2010, p. 190-196). No século XIX, depois de seguir carreira médica, Giovanni Morelli aventurou-se na scienza dell'arte. Com base nos seus conhecimentos fisiológicos, ele propôs uma técnica original, chamada de indiciária, para identificar falsificações ou quadros de atribuição incerta. Para Morelli, ao avaliar uma obra de arte, era preciso observar os detalhes, os fatos marginais, os traços imperceptíveis. Não se tratava de encontrar a solução no sorriso de um Leonardo da Vinci, mas na forma da orelha de um Botticelli. Referindo-se à história da política, a pergunta que Sintomer nos faz é a seguinte: não seria o sorteio o lóbulo da orelha da aventura democrática?

\section{O sorteio ao longo da história}

Não existe consenso sobre a origem da participação de cidadãos comuns na vida pública. Sua existência é possível em civilizações mais remotas, mas foi na Atenas Clássica, com o despertar da democracia, que esse mecanismo se transformou numa forma efetiva de ascensão ao poder, junto com a eleição ou a indicação de pessoas (Manin, 1996). Com a reforma de Clístenes, na segunda metade do século IV a.C., foram consolidadas a Boulé (o Conselho Popular) e a Helieia (formada pelos tribunais). Em ambos os casos, o sorteio foi um componente essencial: cada cidadão, conforme o princípio ho boulomenos ("aquele que desejar"), podia se candidatar para exercer um cargo público. Uma vez sorteado - o

\footnotetext{
pesquisas deliberativas; e vii) o livro de Sintomer (2010), também traduzido para o português, que traz uma das mais influentes reflexões (inclusive para este artigo) já feitas sobre o sorteio, apesar de não contemplar as iniciativas da última década.

${ }^{4}$ Há apenas um experimento relevante envolvendo o sorteio no Brasil, muito pouco divulgado, feito pelo governo do Rio Grande do Sul, em 2009, para avaliar a carreira dos funcionários públicos. O relatório da experiência pode ser conferido em: <http://cdd.stanford.edu/mm/2009/brazil-consulta-deliberativa.pdf>. Acesso em: 29 jun. 2018.
} 
instrumento utilizado era o kleroterion, uma peça de mármore contendo cinco colunas, onde era possível inserir placas -, o cidadão podia exercer funções transversais às que hoje correspondem ao Legislativo, ao Executivo e ao Judiciário. Assim, como dizia Aristóteles (1997, p. 139), a seleção aleatória constituía um contraponto à eleição: enquanto a primeira encarnava os princípios da igualdade e da rotatividade (todos aqueles que fossem considerados cidadãos tinham legitimidade para um dia serem sorteados e participarem da atividade pública), a segunda encarnava os princípios da meritocracia e do poder de influência (os cidadãos mais respeitados, não raro os mais ricos, podiam se candidatar aos cargos públicos). No contexto da Antiguidade, Atenas foi um símbolo da participação popular. Pode-se estimar que mais da metade dos cidadãos, com mais de 30 anos, exerceram cargos na administração pública, desenvolveram funções legislativas ou foram jurados pelo menos uma vez na vida (Finley, 1983; Sintomer, 2010; López-Rabatel, 2017).

Com o declínio da democracia ateniense, após a Guerra do Peloponeso, no final do século V a.C., a participação popular entrou em decadência. As instituições romanas privilegiariam a cultura aristocrática e o uso do sorteio praticamente desapareceu ${ }^{5}$. Foi preciso esperar as repúblicas italianas renascentistas, a partir do século XIII, para que o sorteio voltasse à tona de forma sistemática, apesar de num contexto restrito. Maquiavel (1994) nos narra como em Florença, com a disputa acirrada entre as grandes famílias, diversos nomes eram indicados para as funções públicas, ensejando em seguida um sorteio para a escolha daquele que assumiria o cargo. Essa técnica, cujo modus operandi podia ser extremamente elaborado, variando de cidade para cidade, foi amplamente utilizada, evitando o derramamento de sangue nas lutas pelo poder (Guicciardini, 1994; Sintomer, 2010).

O uso da seleção aleatória na política, porém, estava com seus dias contados. Depois da Grécia e da Itália, essa prática desapareceria da história, levando alguns a se interrogarem sobre os motivos dessa exclusão. Para Manin (1996), numa tese que se tornou clássica, os pais fundadores das democracias americana e francesa, leitores de Aristóteles e Maquiavel, ao fazerem da eleição o auge da democracia, optaram por uma aristocracia eletiva: ao contrário do sorteio, que permitia a participação de todos, o governo representativo permitia a participação dos "melhores".

\footnotetext{
$5 \mathrm{Na}$ verdade, o uso do sorteio ficou restrito aos jurados na esfera judicial. No caso do Brasil, conforme prevê a Constituição de 1988 (art. 5 , XXXXVIII, "d"), o júri popular acontece somente no caso dos crimes dolosos contra a vida (Cf. Castro, 1999).
} 


\section{O resgate do sorteio na democracia}

A democracia liberal, assente na legitimidade da eleição dos seus representantes políticos e na dinâmica do capitalismo (Schumpeter, 1961), foi se consolidando ao longo dos séculos, mas não há dúvidas de que ela entrou em crise (Bougnoux, 2006) ${ }^{6}$. No âmbito político, uma das principais críticas era a falta de capilaridade da democracia representativa. Duas correntes começaram a apontar o abismo cada vez mais acentuado entre governantes e governados: de um lado os "participacionistas", com a grassroots democracy (Fisher, 1993), as iniciativas de empowerment (Berger e Neuhaus, 1977) e os trabalhos precursores de Pateman (1970) e MacPherson (1977); de outro os "deliberacionistas", com o "agir comunicativo" de Habermas (1987), a "razão pública" de Rawls (1971) e o "processo deliberativo" de Cohen (1989). De forma resumida, remetendo a essa vasta literatura que se constituiu ao longo dos anos 1970 e 19807, é possível afirmar que, embora houvesse um consenso entre as duas correntes no sentido de denunciar os limites da representação e de fazer com que a democracia se tornasse mais próxima dos cidadãos, os "participacionistas" defendiam sobretudo a mobilização social, o alargamento da esfera política e a inclusão nesta do maior número de cidadãos, enquanto os "deliberacionistas" buscavam sobretudo aperfeiçoar o processo de formação de vontades, na tentativa de criar procedimentos capazes de formar uma opinião esclarecida8.

Foi nesse contexto de crítica e de tentativa de inovar que o sorteio foi resgatado no começo dos anos 1970. Na Alemanha, Dienel (1970) falou em células de planificação (Planungszellen), enquanto Crosby (1975), nos Estados Unidos, falou em júris de cidadãos (citizens'juries). Concebidas quase ao mesmo tempo, sem que seus idealizadores tivessem conhecimento um do outro, essas duas ideias eram praticamente idênticas, e buscavam recuperar a dinâmica da prática grega de selecionar cidadãos de forma aleatória para exercer uma função pública. A grande novidade, com relação aos Antigos, era o advento da amostra representativa. Idealizada no final do século XIX, a partir do aprimoramento da estatística, junto ao cálculo matemático, essa técnica foi se consolidando ao longo do século $X X$, sendo utilizada primeiro nas estatísticas oficiais dos governos, até se consolidar com os institutos de pesquisa de opinião. Por meio dela, respeitando critérios de sexo, idade e classe social, é possível selecionar aleatoriamente um grupo de pessoas, geralmente a partir das listas eleitorais, constituindo-se uma amostra bastante fiel às

\footnotetext{
6 Diversas foram as causas: uma crescente insatisfação com os representantes políticos (incapazes de atender às aspirações da população); uma burocracia estatal cada vez mais ineficiente (ao contrário do que imaginava Max Weber); uma descrença dos cidadãos (que não acreditavam mais na política tradicional); o advento das ambivalências do progresso (depois de um período de certeza epistemológica); a desconfiança com relação à formação da opinião pública (constituída sobretudo por meio dos grandes veículos de comunicação) etc.

7 É importante destacar o papel do Brasil nessa dinâmica, sobretudo a partir dos anos 1990, com o advento de diversas instituições participativas (Avritzer, 2009).

8 Para uma análise mais completa dessas duas correntes, cf. Pateman (2012), Sintomer (2011b) e Pereira (2007).
} 
diversidades sociais de determinada circunscrição9 ${ }^{9}$ A partir daí, o objetivo de Peter Dienel e Ned Crosby era fazer com que essas pessoas selecionadas - ou seja, um microcosmo da população - pudessem se reunir para deliberar sobre um assunto de interesse público. Havia, assim, dois critérios de legitimidade: o primeiro, sociológico, a partir da amostra representativa (que busca resguardar as diferenças sociais entre os indivíduos selecionados); e o segundo, epistemológico, com a formação de uma opinião esclarecida ou de uma "razão comunicativa" (que se difere substancialmente da opinião pública convencional, praticada pelos institutos de pesquisa, na qual os cidadãos consultados não têm tempo para refletir sobre as questões que Ihes são colocadas).

Aos poucos, as primeiras experiências foram sendo realizadas, formando um modelo estandardizado. É o poder público, na maioria das vezes, quem convoca um grupo de pessoas sorteadas. A seleção da amostra, que gira entre 25 e 50 pessoas, fica a cargo de um instituto de pesquisa de opinião pública. Os cidadãos selecionados se reúnem em plenário ou em subgrupos e geralmente ganham uma indenização pecuniária para participar do procedimento. Um moderador independente é contratado para conduzir os debates. As temáticas variam de planejamento urbano a políticas de saúde, passando por questões sociais e ecológicas. O grupo escuta os especialistas no assunto e as partes envolvidas no processo (associações, políticos, empresários etc.). Os trabalhos geralmente duram de dois a três dias. As decisões dos cidadãos podem ser consultivas ou impositivas. Na Alemanha, um dos casos mais interessantes ocorreu em 1991, quando o ministro dos Correios e das Telecomunicações adotou algumas das recomendações das Planungszellen, em especial sobre a proteção dos dados pessoais. Nos Estados Unidos, dois citizens' juries em 2003 chamaram a atenção: um que debateu o orçamento federal e outro que tratou da reforma do sistema de saúde do presidente Clinton. Na Grã-Bretanha, sob influência do Institute for Public Policy Research, mais de 200 citizens' juries já foram organizados (Sintomer, 2010).

\footnotetext{
9 Smith (2009, p. 79-84) chama a atenção para três possíveis distorções nas amostras representativas. Em primeiro lugar, a incompletude das bases de dados, de onde as amostras são retiradas. No caso das listas eleitorais, por exemplo, nem todos estão registrados. Em segundo lugar, ele alerta para o fato de as pessoas não estarem obrigadas a participar. No experimento (que veremos mais adiante) da Colúmbia Britânica, por exemplo, dos 23.034 convidados, somente 1.715 responderam de forma positiva. Isso pode trazer uma assimetria na amostra, comprovada em algumas experiências, no sentido de que as pessoas mais engajadas politicamente são mais propícias a participar do procedimento, apesar de que, para Smith, não existe uma diferença muito grande de opinião se compararmos esse grupo mais engajado com a população geral. Por fim, ele cita o risco de a amostra deixar de fora algumas minorias, cujas opiniões podem ser essenciais para a legitimidade do procedimento. Nesse sentido, correções têm sido feitas, incluindo nas amostras de alguns experimentos critérios como etnicidade ou até mesmo visões políticas. No próprio caso da Colúmbia Britânica, cidadãos aborígenes (que ficaram de fora da amostra por sorteio) foram incluídos no minipúblico. No caso do G1000 (de que também tratamos mais adiante), 10\% das vagas foram destinadas aos vulneráveis, como moradores de rua e pessoas de origem estrangeira, que ficaram de fora do sorteio.
} 


\section{A diversificação das experiências}

Após as ideias precursoras de Peter Dienel e Ned Crosby, outras iniciativas foram surgindo ao redor do mundo. Uma das mais ousadas, a conferência de consenso, teve início em 1987, quando o parlamento dinamarquês criou o Danish Board of Technology, órgão encarregado de avaliar as questões tecnológicas e de desenvolver o debate público sobre suas implicações. O objetivo era formar painéis de cidadãos sorteados que, após debaterem temas como energia nuclear, clonagem, poluição do ar etc., apresentavam relatórios sobre suas decisões. Inserida no contexto da democratização da ciência (Sclove, 1995; Callon, Lascoumes e Barthe, 2001), a conferência de consenso é um mecanismo capaz de trazer mais legitimidade para um campo que teve sua autonomia contestada ao longo das últimas décadas (Kuhn, 1983; Feyerabend, 1975; Latour, 1987). De fato, a filosofia e a sociologia da ciência vêm nos mostrando que as decisões científicas estão muitas vezes ancoradas em um núcleo epistemológico fragilizado, com diversas teorias e métodos concorrentes, ficando à mercê de redes de interesse e de poder. E é nesse sentido que as escolhas desse campo podem nos remeter menos a critérios técnicos do que a uma reflexão cidadã sobre o tipo de sociedade que queremos viver (Pestre, 2001).

Uma das conferências de consenso mais interessantes aconteceu na França, em 1998, quando um grupo de cidadãos foi reunido na Assembleia Nacional para debater a utilização de um milho geneticamente modificado na agricultura e na alimentação ${ }^{10}$. Requisitado pela comissão parlamentar, o Instituto Francês de Opinião Pública selecionou, aleatoriamente, 14 cidadãos franceses, respeitando os critérios utilizados nas amostras representativas das pesquisas de opinião. Formado o grupo, o procedimento, coordenado por um comitê de pilotagem independente ${ }^{11}$, consistia em três etapas: um estágio de formação sobre os transgênicos, um debate aberto na Assembleia Nacional e uma deliberação dos cidadãos. Boy, Donnet-Kamel e Roqueplo (2000), membros do comitê de pilotagem, mostram que durante o estágio de formação foram convidados diversos especialistas - respeitando as diversidades ideológicas -, para que o grupo de cidadãos, como num verdadeiro curso, ficasse sabendo das principais questões relativas aos transgênicos. Os nomes desses cidadãos foram então revelados, no começo da segunda etapa, realizada na Assembleia Nacional, durante dois dias de seções abertas, que contou com ampla presença da imprensa. Nessa ocasião, o grupo pôde fazer perguntas para mais

\footnotetext{
${ }^{10}$ A iniciativa foi do governo francês que, confrontado com a polêmica que a questão vinha gerando, decidiu animar o debate público. Um comunicado oficial dizia que "a opinião pública permanece indecisa e parece insuficientemente informada. Se nossos concidadãos parecem prontos a aceitar a engenharia genética para a produção de medicamentos, eles estão reticentes em aceitá-la para a alimentação. Apesar da grande experiência científica no campo da engenharia genética, os cidadãos recusam que as decisões que comprometem o futuro sejam tomadas sem a expressão e a confrontação de todas as opiniões. Uma 'conferência de consenso' será organizada com a comissão parlamentar de avaliação das escolhas científicas e tecnológicas" (apud Boy, Donnet-Kamel e Roqueplo, 2000, p. 780).

11 Esse comitê era formado por três pesquisadores especialistas em ciências sociais, responsáveis sobretudo pela vigilância do bom desenvolvimento metodológico da conferência, e quatro pesquisadores especializados em engenharia genética.
} 
de 30 experts, de diversas áreas, para esclarecer todas as suas dúvidas. Finalmente, após mais de dez horas de debate, o grupo se reuniu, a portas fechadas, para redigir um documento deliberativo. Nele se destacavam o pedido de uma moratória na introdução do milho transgênico para o consumo tanto dos seres humanos como dos animais, uma série de precauções extras que deveriam ser tomadas em diversos assuntos que tocam os transgênicos e a necessidade de uma pesquisa eminentemente pública para escapar dos riscos dos interesses privados. Ao fazer um balanço geral do evento, Boy, Donnet-Kamel e Roqueplo não deixam de nos alertar para algumas dificuldades encontradas pelo grupo de participantes e pela organização, mas afirmam que "os 14 cidadãos reunidos na conferência manifestaram uma seriedade e uma capacidade de análise que impôs o respeito de todos, tanto dos experts como dos jornalistas" (Boy, Donnet-Kamel e Roqueplo, 2000, p. 789).

Mas seria a pesquisa deliberativa, mecanismo criado por James Fishkin, concomitante com as conferências de consenso, que iria popularizar o uso do sorteio. Fishkin (1991) parte de uma crítica epistemológica às pesquisas de opinião clássicas, que tinham se tornado uma febre nas democracias ocidentais. Apesar de contarem com o critério de legitimidade da amostra representativa, essas pesquisas não possibilitam uma reflexão aprofundada sobre os temas analisados. Muitas vezes, o cidadão é pego de surpresa, com uma pergunta para a qual não está preparado, sendo obrigado a respondêla de imediato. A proposta de Fishkin é trabalhar com uma amostra mais reduzida, fazendo com que as pessoas sejam instruídas e possam debater sobre o assunto, ou seja, passar de uma "pesquisa de opinião" para uma "pesquisa de opinião deliberativa".

Logo inserida no amplo debate sobre a democracia deliberativa, a ideia de Fishkin fez sucesso. O dinamismo do autor, que se tornou um "empreendedor acadêmico", contribuiu para que diversas pesquisas deliberativas fossem realizadas ao redor do mundo. No método de Fishkin, diferente dos júris de cidadão ou das células de planificação, trabalha-se com uma amostra maior, com um mínimo de 130 pessoas, e pode-se analisar a evolução da opinião dos participantes durante o procedimento. Uma das experiências mais importantes se deu na Austrália, em 2001, quando 344 cidadãos sorteados deliberaram a respeito da relação entre os aborígines e as populações não indígenas. 0 evento de três dias, precedido de reuniões preparatórias, foi realizado no Old Parliament House, transmitido pela televisão, e serviu não para tomar qualquer decisão impositiva sobre o assunto, mas para fomentar o debate público e melhorar a relação entre esses povos (Cook e Powell, 2003). Na Grécia, em 2006, Fishkin ajudou a organizar uma pesquisa deliberativa para designar o candidato à prefeitura do partido socialista grego, o Pasok, no município de Marousi. Durante um dia inteiro, 131 cidadãos sorteados entre os habitantes locais puderam ouvir as propostas dos pré-candidatos, fazer perguntas, trabalhar em pequenos grupos, para depois designar por voto aquele que concorreria à eleição (Buonocore, 2006). Até mesmo na China, na cidade de Zeguo, uma série de pesquisas deliberativas foram realizadas, desde 2005, para que os cidadãos locais pudessem debater 
e deliberar a respeito dos direcionamentos de parte do recurso do município. Essas propostas foram depois encaminhadas para as autoridades locais, que, na maior parte das vezes, seguiram as recomendações dos cidadãos (Baogang, 2012). No Brasil, a única experiência envolvendo sorteio foi uma pesquisa deliberativa organizada pelo governo do Rio Grande do Sul, em 2009, quando 226 cidadãos se reuniram, durante dois dias, para avaliar a valorização das carreiras dos servidores públicos estaduais. Vale destacar também a pesquisa deliberativa de 2009 que envolveu cidadãos de 27 países da União Europeia num debate sobre as eleições para o parlamento europeu; a experiência na Coreia do Sul, em 2011, que tratou da questão da unificação e foi transmitida pela KBS, a maior rede de rádio e televisão do país; sem contar as diversas experiências feitas online, como a série realizada em parceria com o programa de televisão PBS NewsHour. Todos os resultados desses procedimentos podem ser conferidos no sítio do Center for Deliberative Democracy, instituto criado por Fishkin, na Universidade de Stanford ${ }^{12}$.

\section{O boom dos minipúblicos}

A partir desses quatro modelos (júris de cidadãos, células de planificação, conferências de consenso e pesquisas deliberativas), as experiências foram se multiplicando. No campo teórico, outros conceitos surgiram para falar do uso do sorteio na política. Dahl (1989), por exemplo, defendeu que minipopuli de cidadãos selecionados aleatoriamente poderiam ser utilizados, em algumas ocasiões, para aperfeiçoar a legitimidade das poliarquias (ou seja, regimes plurais, competitivos e abertos à participação). Burnheim (1985) definiu como "demarquia" - conceito extraído da obra de Hayek (1993) - uma forma de governo sem Estado ou corpos burocráticos, em que grupos de cidadãos sorteados tomariam decisões. Nagel (1992), numa ideia próxima às pesquisas deliberativas, falou em Deliberative Assemblies on a Random Basis (Darbs). Amar (1984) reivindicou a "votação lotérica", um modelo que mistura eleição de candidatos com sorteio: primeiro, se realizariam eleições e, em seguida, cada candidato teria um percentual de chances de ser sorteado equivalente ao total de votos que recebeu, para garantir a representação de minorias. Amanrich (1999) lançou um manifesto a favor do sorteio, intitulado "La démocratie est morte, vive la clérocratie", sendo o termo "clerocracia" uma referência à máquina usada na Grécia para escolher cidadãos. Wright (2014), ao defender uma utopia socialista, afastada do capitalismo e do estatismo, usou o termo "democracia aleatória". E até mesmo o filósofo esloveno Zizek (2004), falando em "loterocracias", passou a reivindicar o uso do sorteio na política.

Em meio a esse emaranhado de termos, um iria se destacar, prevalecendo na literatura sobre o tema. Fung (2003), inspirado no conceito de Dahl, definiu como

12 Cf. <www.cdd.stanford.edu>. Acesso em: 20 jan. 2018. 
minipúblico os procedimentos que fazem uso do sorteio ${ }^{13}$. Segundo Fung, esses "pequenos grupos" podem envolver dinâmicas de "fórum educativo", de "painel consultivo participatório", de "colaboração participativa para solução de problemas" e de "governança democrática participativa" (2003, p. 340-342). Trata-se então de um mecanismo complementar à democracia representativa, ligado ao "pensamento reformista" e não à "reforma revolucionária" (p. 339).

Desde então as experiências com minipúblicos foram se multiplicando. Uma das mais relevantes aconteceu na Colúmbia Britânica em 2004. O governo local formou uma Assembleia Cidadã de 160 pessoas selecionadas aleatoriamente para deliberar sobre a reforma eleitoral dessa província canadense. O objetivo era acabar com a votação uninominal de um turno, conhecida como first past the post, que impedia a representação das minorias. A lógica por trás da opção pelo sorteio era óbvia: os políticos e os partidos têm interesses próprios e, caso fossem votar essa reforma, poderiam ter em mente mais os interesses particulares do que o interesse público geral. A Assembleia Cidadã se reuniu durante seis fins de semana, até emitir um documento público, aberto a críticas e sugestões, em que constavam as principais alternativas disponíveis para a reforma. Em seguida, a Assembleia se reuniu por mais três fins de semana, em sessões abertas, transmitidas pela televisão, até selecionar um modelo conhecido como single transferable vote, que permitia a eleição de dois a sete deputados em cada circunscrição, sobre uma base proporcional. Para entrar em vigor, no entanto, a proposta ainda precisava ser referendada, com aprovação de $60 \%$ dos votos computados na província. Ela acabou obtendo apenas $57,69 \%$, impedindo que a reforma eleitoral entrasse em vigor. Segundo Sintomer, a complexidade do modelo proposto pela Assembleia (single transferable vote) foi o fator essencial para um resultado que, apesar de decepcionante, serviu para revelar o potencial do sorteio: desde a Antiguidade, jamais um grupo de cidadãos selecionados ao acaso tinha assumido tamanha responsabilidade na democracia $(2010, \text { p. 138-140 })^{14}$.

\footnotetext{
13 É importante destacar que Fung (2003) não limita os minipúblicos às experiências com sorteio. Nesse texto, ele cita cinco exemplos de "pequenos grupos" deliberativos: as pesquisas deliberativas; o America Speaks Citizen Summit; o Oregon Health Plan; o Chicago Community Policing; e o Orçamento Participativo de Porto Alegre. Destes, apenas a pesquisa deliberativa faz uso do sorteio. Goodin e Dryzek (2006), com algumas diferenças com relação às ideias de Fung, também incluíram no conceito de minipúblico experiências que não fazem uso da seleção aleatória. Já Smith, apesar de falar que os minipúblicos são constituídos "sobretudo por sorteio" (2009, p. 72), ou seja, não exclusivamente por sorteio, cita no seu livro como exemplos de minipúblicos apenas experiências que fazem uso da seleção aleatória. É possível que o principal motivo para a associação e a consolidação que vêm sendo feitas do conceito de minipúblico com o uso de sorteio seja o fato de Dahl (1989), no qual Fung se inspirou, se referir exclusivamente ao sorteio quando fala de minipopulus. Vale destacar também que, nos textos mais recentes sobre o tema publicados no Brasil, Sintomer (2010) e Rubião (2013) utilizaram o termo júris de cidadãos, de forma genérica, implicando todas as iniciativas que fazem uso da seleção aleatória na política. Esse uso se deu num período em que ainda havia uma indefinição - e até mesmo uma batalha em torno da preponderância dos conceitos - no seio da literatura especializada no assunto. No entanto, o próprio Sintomer (2011a, 2017) foi aos poucos abandonando a nomenclatura júris de cidadãos (no sentido genérico), passando a adotar o termo minipúblico.

${ }^{14} \mathrm{~A}$ experiência da Colúmbia Britânica acabou influenciando mais duas tentativas semelhantes de reforma eleitoral por meio de minipúblicos, uma na província de Ontário (no próprio Canadá) e outra na Holanda, sendo que, na primeira, o referendo final obteve somente $39,9 \%$ de aprovação e, na segunda, o governo
} 
O caso da Islândia foi ainda mais audacioso. Após a crise financeira de 2008, uma forte mobilização social surgiu no país, dando início à chamada "Revolução das Panelas e Frigideiras", que obrigou o governo a antecipar as eleições. Concomitantemente, sob a iniciativa da associação civil The Anthill, um Fórum Nacional de 1.500 pessoas (1.200 sorteadas e 300 indicadas) se reuniu para debater propostas para uma reforma da Constituição do país. O novo governo eleito, favorável ao movimento, decidiu então instituir um procedimento oficial de reforma constitucional e, junto com a Anthill, organizou um segundo Fórum Nacional, com 950 cidadãos selecionados de forma aleatória, para debater e redigir um documento que indicasse quais deveriam ser os principais eixos da reforma constitucional. Em seguida, um Conselho Constitucional composto de 25 cidadãos foi eleito pela população (os políticos não puderam se candidatar), com o objetivo de formular uma nova Constituição. A Suprema Corte do país acabou anulando esse modelo de assembleia constituinte, mas o governo decidiu ignorar a decisão e acabou ratificando a criação do Conselho formado pelos 25 cidadãos. O grupo começou então um intenso trabalho, de forma transparente e participativa, não somente publicando os artigos da nova Carta Magna na internet à medida que eles iam sendo redigidos, mas possibilitando também a contribuição de qualquer cidadão por meio das redes sociais (Facebook, Twitter, Flickr etc.). Concluído o texto, a próxima fase do processo consistia num referendo nacional. Este aconteceu em novembro de 2012 e dois terços da população votante confirmaram o projeto de reforma. Faltava ainda uma última etapa, que era a aprovação da nova proposta de Constituição pelo Parlamento, o que acabou não acontecendo. Uma série de fatores contribuiu para esse resultado decepcionante: as mudanças no quadro político do país, as pressões de alguns setores do poder econômico, a complexidade do procedimento etc. Como disse Landemore, na abertura de um dos principais artigos sobre o tema, "escrever uma Constituição é negócio sério" (2015, p. 166), ou seja, nem todos estavam preparados para uma ousadia democrática daquela envergadura.

Apesar de não ter sido concluído, o caso islandês acabou influenciando as iniciativas que estavam por vir. O experimento da Irlanda foi o maior exemplo disso. Em 2012, o parlamento convocou uma Convenção Constitucional, formada por 33 políticos designados e 66 cidadãos sorteados. O objetivo dessa convenção, que podia ouvir a opinião de experts e receber comentários da população, era emitir pareceres a respeito de oito propostas específicas de reforma constitucional, sendo que esses documentos, em seguida, deveriam ser encaminhados para o parlamento, para o governo e, por fim, referendados junto à população. Ao final do processo, apenas uma das oito questões, referente ao casamento

desistiu de levar a cabo o experimento, apesar de o minipúblico ter se reunido e debatido sobre o assunto. $\mathrm{Na}$ esteira de Van Reybrouck (2017, p. 137-139), que se refere às três iniciativas, podemos apontar as seguintes causas dos fracassos: i) a falta de esclarecimento da população sobre o assunto no momento dos referendos, o que contrasta com a opinião informada dos participantes das assembleias cidadãs; ii) o interesse de alguns partidos em não concretizar as mudanças propostas; iii) a desconfiança dos meios de comunicação; iv) a falta de uma campanha de comunicação profissional, capaz de explicar as razões das escolhas feitas pelos cidadãos; v) o receio de apostar numa mudança (if you don't know, say no). Para uma análise aprofundada do caso da Colúmbia Britânica, cf. Warren e Pearse (2008). 
homoafetivo, foi aprovada pelos irlandeses, obtendo 79\% de aprovação na Convenção e $62 \%$ no referendo. Como observa Van Reybrouck (2017, p. 146-147), pela primeira vez uma mudança constitucional era feita a partir do uso do sorteio; e se compararmos esse caso da Irlanda ("católica") com o da França ("libertária"), referente à adoção do casamento homoafetivo, veremos que, enquanto o primeiro, feito de forma inovadora, com ampla participação cidadã ${ }^{15}$, transcorreu de forma bastante tranquila, o segundo, feito a partir de um projeto de lei tradicional, gerou uma enorme polêmica e um clima de tensão no país.

Por fim, vale a pena citar a plataforma G1000, na Bélgica, que vem influenciando diversas outras experiências espalhadas pelo mundo. Após a enorme crise política de 2010, quando o país ficou 541 dias sem conseguir um acordo para designar seu primeiroministro, um grupo de intelectuais e cidadãos belgas, engajados em diferentes causas, decidiu "fazer alguma coisa" (Jacquet e Reuchamps, 2016). A plataforma foi organizada em três etapas. Em primeiro lugar, uma consulta pública foi disponibilizada na internet, com o objetivo de diagnosticar os principais temas que a população belga gostaria de levar para um debate público. Além de sugerir ideias (mais de 2 mil foram propostas), os cidadãos podiam votar naquelas que consideravam mais relevantes, o que permitiu aos organizadores fazer uma seleção. Em segundo lugar, um grupo formado por 900 cidadãos e 100 selecionados $^{16}$ se reuniu em Bruxelas, durante um dia, para debater e deliberar a respeito dos temas levantados na fase anterior. Em paralelo, foram estabelecidos o GHome (uma plataforma que organizava na internet o mesmo debate que estava acontecendo no G1000) e os G-Off's (em que cidadãos espalhados pelo país também se encontravam de forma presencial para conversar sobre os temas do G1000). Já a terceira fase, denominada G-32, visava elaborar propostas concretas a partir das discussões anteriores. Nela, 32 cidadãos da segunda fase foram selecionados por sorteio. Eles se encontraram durante três fins de semana para debater sobre diversos aspectos da questão do trabalho, tema escolhido pelos próprios participantes. Finalmente, no dia 11 de novembro de 2012, o grupo apresentou um relatório para os presidentes das câmaras parlamentares ${ }^{17}$, com recomendações sobre esse assunto. Segundo Jacquet e Reuchamps (2016), apesar de a qualidade da deliberação ter surpreendendo todos aqueles que acompanharam o procedimento, seja presencialmente ou pela repercussão na imprensa, as proposições do G1000 acabaram não influenciando a agenda do governo belga, segundo eles sobretudo pelo fato de o procedimento ter preservado uma independência com relação aos partidos políticos e instituições públicas. A repercussão do G1000, no entanto, foi enorme. Na própria Bélgica, o município de Grez-Doiceau organizou uma plataforma

\footnotetext{
15 Ao debater o tema do casamento homoafetivo, a Convenção Constitucional recebeu mais de mil contribuições de outros cidadãos (Van Reybrouck, 2017, p. 146).

16 O objetivo de destinar $10 \%$ das vagas para cidadãos selecionados era corrigir as distorções da amostra (cf. nota 6 acima). Os organizadores consultaram algumas associações que indicaram, por exemplo, moradores de rua e pessoas de origem estrangeira.

17 Disponível em: <www.g1000.org>. Acesso em: 25 jan. 2018.
} 
reduzida, o G100, para tratar de assuntos locais, constituindo dez grupos de trabalho para lidar com questões de mobilidade, preservação ambiental, convivialidade, autonomia energética etc. ${ }^{18}$. Na Holanda, sob forte influência de Van Reybrouck, um dos principais idealizadores do G1000, cidades como Amsterdã, Haia, Amersfoort, Groningen, Nijmegen, dentre outras, organizaram experiências semelhantes (Van Reybrouck, 2017, p. 188-189).

\section{Os desafios do sorteio}

Essa multiplicação dos minipúblicos, incluindo iniciativas que trouxeram mudanças estruturais, revela o potencial de reinserção do sorteio na democracia. Não se trata mais de uma simples experimentação, apesar de a desconfiança continuar sendo um desafio. $O$ debate que ocorreu no Podemos, na Espanha, mostra que até mesmo algumas pessoas que lutam contra o status quo na política parecem temer a seleção aleatória. Em 2014, durante uma Assembleia Cidadã que se reuniu para debater os rumos do partido, quando o grupo Sumando Podemos propôs introduzir cidadãos sorteados, de forma complementar, em cargos de direção do movimento ${ }^{19}$, alguns líderes do grupo Claro que Podemos (CQP), como Pablo Iglesias e Carolina Bescansa, dirigiram-lhe duras críticas, falando que o sucesso do Podemos estava ligado à eficácia do movimento, razão pela qual eles não podiam deixar de escolher os melhores candidatos para ocuparem os cargos de poder (a proposta do CQP era um voto em lista) e nem correrem o risco de serem ridicularizados pela imprensa a partir de ideias não razoáveis como aquela referente ao sorteio. Como observa Feenstra (2017), trata-se de uma reação exagerada, uma vez que o sorteio incidiria somente de forma complementar, sem substituir a eleição por voto, e que destoa das reivindicações dos indignados das praças, revelando-se mais próxima da tradicional verticalidade dos partidos do que de uma estrutura política mais horizontal ${ }^{20}$.

De fato, como observa Smith (2009, p. 94-101), a desconfiança com relação à seleção aleatória passa por esse receio com relação ao esclarecimento dos sorteados na deliberação e o risco da influência de argumentos irracionais. Trata-se de preocupações legítimas, apesar de as evidências empíricas revelarem muito mais um otimismo do que

\footnotetext{
18 Para o relatório das atividades que foram propostas pelo G100 e o resultado prático de algumas delas, cf. <www.grezentransition.be>. Acesso em: 28 jun. 2018.

19 De forma resumida, a proposta do Sumando Podemos, para preenchimento de cargos por sorteio no partido, era a seguinte: eleição de $20 \%$ dos integrantes do Consejo Ciudadano, de $25 \%$ dos representantes dos Consejos Ciudadanos Territoliales e dos Consejos Ciudadanos Municipales, e 40\% dos membros da Comissión de Derechos y Garantias (Feenstra, 2017).

$20 \mathrm{Na}$ opinião de Feenstra (2017), a introdução do sorteio poderia trazer: i) igualdade de oportunidades, no sentido de colocar pessoas "comuns" em cargos de direção do partido; ii) independência, no sentido de que essas pessoas não precisariam de apadrinhamentos dentro do partido; iii) pluralidade, no sentido de valorizar a "diversidade cognitiva" e evitar as "espirais de silêncio"; iv) coerência, no sentido de valorizar a horizontalidade e de ousar realizar uma mudança que foi demandada pelas ruas. É importante destacar que, apesar da derrota, em 2014, a militância pelo sorteio persistiu no seio do Podemos. O tema voltou a ser debatido, em 2016, até que na Assembleia de 2017 o coletivo Profundizar el Cambio conseguiu aprovar a eleição por sorteio de 10 integrantes (do total de 56) dos membros do Consejo Autonómico. Cf. Moreno Pestaña (2017).
} 
um temor por parte dos analistas. As experiências têm mostrado não somente que os cidadãos sorteados são capazes e levam a sério o seu papel (Boy, Donnet-Kamel e Roqueplo, 2000; Parkinson, 2006; Sintomer, 2010; Mackenzie e Warren, 2012) ${ }^{21}$ como também estão aptos a irem formando uma opinião mais esclarecida ao longo do procedimento (Ackerman e Fishkin, 2004; Smith, 2009)22. De maneira mais ampla, essas desconfianças estão ligadas à questão da accountability e da responsabilidade dos participantes. Na democracia representativa, como mostrou Manin (1996), uma das maneiras de prestar contas, além de respeitar exigências legais, é encarar a reeleição. Mas e no caso do sorteio? De que maneira é possível controlar a responsabilidade dos cidadãos?

Esse talvez seja um dos principais desafios dos minipúblicos (Parkinson, 2006) ${ }^{23}$. Tanto é que, na visão de Sintomer (2010, p. 155-156), "se os mecanismos baseados no sorteio atingissem uma escala maior, seria necessário enquadrá-los numa legislação"24. Enquanto isso não ocorre, outras iniciativas são usadas para dirimir o problema. No caso da Colúmbia Britânica e em alguns júris de cidadãos, por exemplo, regras de conduta ou declarações de comprometimento com determinados valores foram instituídas pelos participantes (Smith e Wales, 2000; Smith 2009). A questão da transparência também é fundamental. Nesse sentido, o caso da Islândia talvez seja o mais inspirador, em especial pela ampla e imediata disponibilização na internet do conteúdo dos debates (Landemore, 2015); isso sem contar a presença de observadores independentes, como ocorrido em diversas experiências, que também contribui para a credibilidade como um todo. Por fim, é preciso destacar o papel dos moderadores e a necessidade de capacitá-los, desenvolvendo uma expertise em torno desses profissionais responsáveis pelos procedimentos. Durante os debates, eles devem observar a distribuição equânime de tempo, tentar solucionar as dúvidas dos cidadãos sorteados, fazer com que eles não percam o foco do tema proposto etc. Afinal, a isenção da equipe organizadora é fundamental e a dinâmica proposta pode influenciar diretamente nos resultados (Thompson e Hoggett, 2002). Em especial, para Fung (2003, p. 344), os moderadores devem ficar atentos às "desvantagens daqueles que não falam tão bem ou falam de uma forma que possam ser desvalorizados pela cultura dominante". Segundo ele, os minipúblicos devem ser construídos de modo a "permitir àqueles que não têm voz e vontade encontrá-las e constituí-las" e seus organizadores devem "assegurar que os mais fracos, e não necessariamente aqueles com melhores ideias e argumentos, tenham tempo

21 Sintomer (2010, p. 155) afirma que a "dinâmica das deliberações induz um controle mútuo dos participantes e a pessoa que se comporta de maneira 'irresponsável' perde rapidamente a credibilidade".

22 Ackerman e Fishkin (2004) mostram diversas evidências nesse sentido, como, por exemplo, oito pesquisas deliberativas ocorridas no Texas, onde o percentual de participantes dispostos a pagar mais por energia renovável subiu de $52 \%$ para $84 \%$.

23 Nem mesmo Fishkin (1991), um dos grandes defensores do uso do sorteio, tendo em vista a falta de accountability e de responsabilidade dos cidadãos, acredita que eles devam ter voz final nas decisões, funcionando apenas como orientadores de uma opinião pública esclarecida sobre determinado tema.

${ }^{24}$ Courant (2017) chama a atenção para o fato de em Atenas a responsabilidade e a prestação de contas por parte dos cidadãos sorteados serem extremamente importantes, podendo as sanções variar entre pequenas multas, exílio e até mesmo execução. 
amplo para falar e se exprimir" (Fung, 2003, p. 344)25. De um modo geral, Smith mostra que a avaliação desses profissionais é muito boa. No caso da Colúmbia Britânica, por exemplo, embora tenham sido constatadas algumas reclamações, a percepção geral dos participantes (avaliada ao longo do experimento) e dos observadores externos (incluindo a imprensa) foi bastante positiva no que toca ao profissionalismo, à neutralidade e ao compromisso da equipe organizadora (Smith, 2009, p. 86-91). Há ainda outras discussões (seja com relação ao tamanho da amostra, ao tempo de deliberação, à necessidade ou não de publicização dos debates etc.) e de fato inexiste um consenso na literatura sobre o modelo ideal, mas não há dúvida de que o acúmulo e a troca de experiências podem contribuir para superar esses desafios e aperfeiçoar o desenho institucional dos procedimentos com sorteio (Smith, 2009). Sintomer (2010, p. 170-171) sugere até mesmo a criação de uma Fundação Nacional para a Democracia Participativa capaz "de permitir uma dinâmica cumulativa, a partir da qual fosse possível comparar experiências, divulgando as práticas bem-sucedidas e evitando os mesmos erros".

Outra crítica ao sorteio que merece atenção é aquela que denuncia a ausência de uma identidade de grupo (Young, 2006) ou da formação de contraesferas públicas (Fraser, 1990, 2009). Nesse sentido, os minipúblicos sorteados impediriam uma participação espontânea da sociedade, por meio de associações, grupos de interesse, lideranças políticas etc. Além de essas pessoas terem legitimidade junto ao corpo social, elas adquirem um know-how que é importante para a deliberação de temas de interesse da população. A seleção aleatória de cidadãos comuns é vista então como um mecanismo tecnicista que impede a formação de uma opinião pública natural ${ }^{26}$. Essa crítica foi levada a sério pelos teóricos do sorteio e algumas alternativas começaram a surgir. O orçamento participativo de Berlim é um exemplo (Rubião e Anversa, 2015). Entre 2001 e 2003, a prefeitura disponibilizou 500 mil euros para cada um dos 17 bairros economicamente frágeis da capital alemã. No começo, cogitou-se adotar o modelo de Peter Dienel, mas os organizadores acabaram inovando: os minipúblicos seriam compostos por $51 \%$ de pessoas

\footnotetext{
25 A divisão da amostra em grupos menores também pode contribuir para que as pessoas participem de forma mais ativa (Smith, 2009, p. 98).

26 Para Young (2006, p. 172), "muitos dos que advogam a representação específica de mulheres, ou de afroamericanos, ou de classes ou de aborígenes, achariam absurda a sugestão de que atributos físicos ou de pertencimento em si mesmos poderiam fundamentar a representação de determinadas pessoas por outras com atributos semelhantes. Em vez disso, argumentam eles, mulheres, aborígenes etc. têm experiências semelhantes que apenas os membros de seus próprios grupos podem compreender com o mesmo imediatismo. Para outros, contudo, justificar a representação de grupos em termos de experiências, interesses ou opiniões suspostamente compartilhadas por todos os membros do grupo obscurece as diferenças internas deste e erroneamente reduz todos os membros a uma essência comum, de modo que os grupos se tornariam de tal forma distintos uns dos outros que lhes seriam impossíveis o entendimento e a cooperação em suas diferenças". Vale a pena mencionar também o argumento de Fraser (1990, 2009), que, desde sua crítica à teoria de Habermas, vem atacando a unidade da esfera pública, por conta de seus mecanismos de exclusão, defendendo contraesferas públicas, formada por grupos dominados. Nesse sentido, o sorteio também seria responsável por um espaço unitário e, mesmo que seja possível diversificá-lo, com a técnica da amostra, os grupos dominados não seriam capazes de, dialogando entre si, solidificar uma opinião pública, motivo pelo qual faltaria legitimidade.
} 
sorteadas a partir das listas policiais ${ }^{27}$ e por $49 \%$ de cidadãos reconhecidamente ativos em suas comunidades, oriundos de associações de moradores, organizações não governamentais, dentre outros grupos atuantes na localidade. Tratava-se então de um modelo misto ou de um "fórum híbrido" (Callon, Lascoume e Barthe, 2001) que contemplava tanto os cidadãos comuns, sorteados a partir de amostra representativa, como os cidadãos engajados, que podiam se cadastrar como participantes ${ }^{28}$. Para além do orçamento participativo de Berlim, os próprios casos da Islândia e da Irlanda, ao conjugarem amostras de cidadãos sorteados com debates na internet, mostram que é possível diversificar os mecanismos, de modo que os minipúblicos não fiquem isolados da participação espontânea da sociedade ${ }^{29}$.

Por outro lado, se levarmos em conta essa dinâmica que envolve o debate entre "participacionistas" e "deliberacionistas", podemos usar um argumento semelhante em favor das práticas com sorteio. Afinal, os instrumentos clássicos de participação - como o orçamento participativo ou os conselhos de políticas públicas no Brasil - muitas vezes deixam de fora o cidadão comum, aquele que não se interessa pelo debate público. Fora isso, nesses mecanismos há sempre o risco de cooptação (pelas esferas de poder, ligadas aos partidos) e a possibilidade de formar um grupo fechado de "experts da participação". O sorteio possui o mérito de poder colocar em cena pessoas que não têm costume de participar da política, seja na esfera da democracia representativa ou da democracia participativa espontânea. Essa inclusão do cidadão comum vai ao encontro daquilo que Phillips (1995) definiu como a "política da presença", ou seja, o fato de a representação depender das características sociais dos representantes. Formados a partir de amostras representativas, os minipúblicos são capazes de atender a essa exigência sociológica, que vê na diversidade uma condição sine qua non da deliberação. Esse mesmo argumento vem sendo defendido por Landemore (2015), no sentido de que há um ganho epistemológico com a formação de uma "inteligência coletiva", em que todas as vozes podem participar, sendo os minipúblicos um dos mecanismos mais instigantes para formar aquilo que ela define como "razão democrática". É preciso deixar claro que isso não significa uma exclusividade ou uma preponderância do sorteio na democracia. Como defenderam Mansbridge et al. (2012), é necessário ir além da análise de iniciativas isoladas e pensar o sistema deliberativo como um todo, ou seja, inserido numa rede complexa que envolve o poder público, a mídia, as associações, a sociedade civil, o sistema educativo etc. Dessa

\footnotetext{
$27 \mathrm{Na}$ Alemanha, todas as pessoas, até mesmo os estrangeiros que têm uma vida estável no país, devem ter um registro na polícia.

${ }^{28}$ Após o registro, caso houvesse um número excessivo de associações querendo participar, era feito um sorteio entre elas.

29 Nesse sentido, o conjunto das experiências mais recentes envolvendo a seleção aleatória (Berlim, Islândia, Irlanda, G1000) reduz a distância entre o Norte e o Sul. Baggia (2017, p. 71), por exemplo, ao comparar as duas tradições, afirma que os mecanismos que fazem uso do sorteio são alheios à tradição cívica latinoamericana, ligada à mobilização da sociedade civil e à abertura a todos que queiram participar. No entanto, seja destinando $50 \%$ das vagas à participação espontânea (Berlim), seja conjugando a amostra sorteada com a possibilidade de mobilização e participação social (Islândia, Irlanda e G1000), é possível perceber que esse argumento deve ser nuançado.
} 
forma, a opção por um determinado desenho institucional deve sempre levar em conta as características do caso concreto, de modo a potencializar os ganhos de legitimidade democrática ${ }^{30}$.

\section{A utopia do parlamento sorteado?}

Uma das grandes questões envolvendo o sorteio na política é saber até onde essa iniciativa pode chegar. As experiências das últimas décadas vêm mostrando a diversidade e o potencial dos minipúblicos. Tendo em vista os procedimentos levantados ao longo deste artigo, é possível classificá-los em quatro categorias: i) consultivos, quando são convocados para emitir um parecer sobre determinado assunto, sem que o poder público ou a autoridade que os constituiu seja obrigada a levar em conta essa opinião (conferências de consenso, citizens' juries organizados pelo Institute for Public Policy Research); ii) deliberativos, quando a decisão do minipúblico sobre um tema predeterminado e limitado vincula o poder público ou a autoridade competente (orçamento participativo de Berlim, indicação do candidato à prefeitura do partido socialista grego); iii) fomentadores do debate público, quando o objetivo é promover uma reflexão na sociedade sobre um determinado tema (pesquisas deliberativas sobre a unificação das Coreias e sobre a relação entre os aborígines e as populações não indígenas na Austrália); iv) propositivos, quando os minipúblicos têm uma autonomia maior para definir a agenda da deliberação, remetendo o resultado ao poder público ou à autoridade competente, que pode aprová-lo diretamente ou submetê-lo a aprovações do Legislativo ou da população por meio de referendos (casos da Islândia, da Irlanda e da plataforma G1000). Mas muitos acreditam que a seleção aleatória pode ir além.

Nesse sentido, a proposta mais ousada é a criação de um parlamento formado por pessoas sorteadas ${ }^{31}$. Um dos primeiros manifestos a favor dessa ideia se deu nos Estados Unidos, com o livro A citizen legislature, de Callenbach e Phillips (1985). A proposta dos autores era clara: transformar a House of Representatives, constituída por 435 deputados eleitos no âmbito federal, numa Representative House, formada por 435 cidadãos

\footnotetext{
30 Mansbridge et al. (2012, p. 5-6) citam o caso da iniciativa do Reino Unido de inserir a deliberação pública, por meio de júris de cidadãos, na formulação das políticas de saúde (Cf. Parkinson, 2006). Muito além do minipúblico, a dinâmica contemplava profissionais da saúde, sindicatos, ativistas, administradores, grupos de caridade e diversas esferas do poder público. Assim, a análise deliberativa sistêmica "leva em consideração não apenas um fórum particular ou um tipo de inovação, mas o papel do fórum ou da inovação no sistema deliberativo mais amplo, permitindo-nos compreender, em termos de democracia, seus pontos fracos e fortes, inseridos na dinâmica que envolve grupos e níveis distintos numa escala maior" (Mansbridge et al., 2012, p. 6). Nesse sentido, tendo em vista a realidade brasileira, com diversas instituições participativas solidificadas, é preciso avaliar até que ponto o sorteio pode ser inserido, de modo que a iniciativa possa ser vista com legitimidade.

31 Muitos autores criticam o fato de as iniciativas com sorteio não terem autonomia para propor mudanças estruturais na política (Goodin e Dryzek, 2006; Smith, 2009; Pateman, 2012). Não há dúvidas de que um parlamento sorteado seria a proposta mais radical para superar essa deficiência, mas é importante notar que algumas dessas análises (Goodin e Dryzek, 2006; Smith, 2009) citavam o caso da Colúmbia Britânica como exceção. Desde então, em especial com os experimentos da Islândia e da Irlanda, é possível perceber novas iniciativas em que foi possível propor mudanças estruturais.
} 
sorteados, ou seja, essa nova casa parlamentar teria praticamente as mesmas funções da antiga, coexistindo com o Senado, que permaneceria ligado ao voto popular. Apesar da reputação dos autores (Callenbach havia escrito um best-seller da causa ecológica, chamado Ecotopia, e Phillips havia criado a Mastercard), a ideia da Câmara de Cidadãos teve pouca repercussão, sendo vista como algo exótico. Foi preciso esperar o boom dos minipúblicos para ela voltar à tona. Van Reybrouck (2017), na sequência de Vergne (2010), fez um diagnóstico de mais de 20 manifestações a favor de parlamentos sorteados, que vão das iniciativas no Reino Unido de Barnett e Carty (1998), passando pela proposta para a União Europeia de Buchstein (2009) e pelo complexo modelo de Bouricius (2013), até as recentes mobilizações de cidadãos na Suíça para instituir um referendum sobre a transformação do Nationalrat. É verdade que a ideia continua sendo vista como muito audaciosa, mas ela revela que os teóricos do sorteio são capazes de levar esse mecanismo até suas últimas consequências. E como disse Blake (1996, p. 77), na sua série de poemas proféticos, "o que agora é provado foi uma vez apenas imaginado".

\section{Conclusão}

Na última eleição presidencial francesa o sorteio adquiriu um papel interessante. O mecanismo esteve presente nas propostas de vários candidatos: Emmanuel Macron, por exemplo, sugeriu um órgão de cidadãos sorteados para supervisionar o presidente; o concorrente do Partido Socialista, Benoît Hamon, lançou a ideia de constituir um minipúblico formado por parlamentares e cidadãos selecionados aleatoriamente, com o objetivo de traçar os contornos de uma nova República; já o candidato da extremaesquerda, Jean-Luc Mélenchon, prometeu criar uma assembleia constituinte formada por cidadãos sorteados, a exemplo do que aconteceu na Islândia; outros candidatos menos badalados, como Charlotte Marchandise e Alexandre Jardin, também incluíram nos seus programas iniciativas envolvendo o sorteio ${ }^{32}$. Essa informação é importante. Trata-se de diferentes posições no tabuleiro político, algo que indica a diversidade ideológica em que a seleção aleatória pode transitar. A campanha presidencial francesa de 2017 também mostrou que o sorteio vem ganhando cada vez mais legitimidade. Parece que a ideia de um "retorno aos gregos", no sentido de recompor a estrutura da democracia, entrou de vez no debate político.

De fato, pouco mais de um século depois da constatação de Robert Michels (1910), a chamada "lei de ferro da oligarquia", não há dúvidas de que o sorteio surge como uma das principais alternativas para escapar dessa cilada. Não se trata de reverter a democracia representativa, nem tampouco de abandonar a participação espontânea da sociedade ou outros desenhos institucionais deliberativos. Ao longo deste artigo, vimos diversas iniciativas que conjugam o sorteio com as instituições tradicionais de representação e com

32 Ver: <www.lci.fr/politique/le-tirage-au-sort-en-politique-hamon-melenchon-et-macron-le-proposentune-idee-neuve-2027211.html>. Acesso em: 6 fev. 2018. 
práticas de mobilização e participação social. Mas a entrada em cena dos "profanos na política" (Fromentin e Wolcik, 2008) vem trazendo uma novidade: ela nos mostra que as pessoas comuns - desligadas de partidos, instituições, burocracias ou movimentos "sagrados" - são capazes de deliberar sobre temas de interesse geral, trazendo consigo uma imparcialidade e um saber-cidadão imprescindíveis para transformar uma esfera pública carregada de interesses e de redes de poder ${ }^{33}$.

Muito além disso, o sorteio pode contribuir para uma verdadeira "escola da democracia" (Mansbridge, 1999; Talpin, 2011). Essa constatação já havia sido feita por Tocqueville ao visitar a América jacksoniana. Era a "época de ouro" dos júris da esfera judicial, quando eles podiam se pronunciar sobre questões de direito, chegando ao ponto de flexibilizar as leis estatais. Sem adentrar no âmbito jurídico, Tocqueville dizia apreciar sobretudo o potencial político e pedagógico desse mecanismo: "o júri, que é o meio mais energético de fazer reinar o povo, é também o meio mais eficaz de ensiná-lo a reinar" (1977, p. 213); "devemos considerá-lo como uma escola gratuita e sempre aberta" (1977, p. 211).

Numa sociedade complexa, com dificuldade de auferir legitimidade para suas decisões, não podemos negligenciar esse potencial de autogoverno. O sorteio pede passagem. Sinônimo de democracia para os gregos, ele foi preterido em favor de uma república aristocrática. Mas se muitos acreditavam que esse mecanismo havia desaparecido, o advento da técnica da amostra representativa permitiu uma reviravolta na história. Passada a fase experimental, com iniciativas que remontam aos anos 1970, não há dúvidas de que o sorteio vem se consolidando como uma alternativa viável para transformar as democracias contemporâneas.

\footnotetext{
33 O uso do sorteio por meio de amostra representativa pode ser pensado até mesmo na esfera do Judiciário. Häberle (1997) foi o mais importante defensor da ideia de "abertura dos intérpretes da Constituição", ou seja, o argumento de que os juízes não podem deixar de levar em consideração a compreensão dos demais envolvidos no julgamento, sejam eles a sociedade civil organizada, a opinião pública, os acadêmicos, a mídia etc. Com isso, Häberle influenciou diretamente algumas inovações institucionais no Brasil, como a figura do amicus curiae (Del Prá, 2007) e as audiências públicas realizadas pelo STF (Marona e Rocha, 2014). Em ambos os casos, no entanto, temos a presença da sociedade civil organizada ou de experts que mostram seu ponto de vista para os juízes da Corte. De modo distinto, um minipúblico poderia ser formado por cidadãos comuns para que estes também dessem sua opinião sobre o tema (como, por exemplo, nos casos do aborto de fetos anencéfalos e da descriminalização da maconha). O minipúblico seria apenas consultivo e seu principal objetivo seria mostrar para a Corte uma opinião pública esclarecida, de modo a contribuir para aquilo que Häberle (2003) define como o "pensamento das possibilidades", ou seja, as escolhas razoáveis dentro do quadro constitucional.
} 
O SORTEIO NA POLÍTICA: COMO OS MINIPÚBLICOS VÊM TRANSFORMANDO A DEMOCRACIA

\section{Referências bibliográficas}

ACKeRmAn, B.; FISHKIn, J. Deliberation day. New Haven: Yale University Press, 2004.

AMANRICH, F. La démocratie est morte, vive la clérocratie! Ou la clérocratie comme alternative à la démocratie. Paris: Barré \& Dayez, 1999.

AMAR, A. R. "Choosing representatives by lottery voting". The Yale Law Journal, vol. 93, n 7, p. $1.283-1.308,1984$.

ARIStóteles. Política. 3a ed. Brasília: Editora da UnB, 1997.

AVRITZER, L. Participatory institutions in democratic Brazil. Baltimore: Johns Hopkins University Press, 2009.

BAGgIA, F. "Governos de esquerda e participação na América Latina: um estudo das instituições participativas no Brasil e na Venezuela". Tese de doutorado, Universidade Federal de Minas Gerais, Belo Horizonte, 2017.

BAOgANG, H. Participatory budgeting in China. An overview. In: SinTOMER, Y.; TrAub-MeRZ, R.; ZHANG, J. (eds.). Participatory budgeting in Asia and Europe: key challenges of deliberative democracy. Hong Kong: Palgrave, 2012.

BARNETT, A.; CARTY, P. The Athenian option: radical reform for the House of Lords (luck of the draw: sortition and public policy). Charlottesville: Imprint Academic, 1998.

Berger, P. L.; Neuhaus, R. J. To empower people. From State to civil society. Washington: American Enterprise Institute, 1977.

BLAKE, W. Selected poetry. New York: Oxford University Press, 1996.

Bougnoux, D. La crise de la représentation. Paris: La Découverte, 2006.

BouRICIUS, T. "Democracy through multi-body sortition. Athenian lessons for the modern day". Journal of Public Deliberation, vol. 9, n 1, p. 1-19, 2013.

Boy, D.; Donnet-Kamel, D.; Roqueplo, P. "Un exemple de démocratie participative: la "conférence de citoyens" sur les organismes génétiquement modifiés". Revue Française de Science Politique, ano $50, n^{\circ s} 4-5$, p. $779-809,2000$.

BUCHSTEIN, H. "Randomizing Europe: the lottery as a decision-making procedure for policy creation in the EU". Critical Policy Studies, vol. 3, n 1, p. 29-57, 2009.

Buonocore, M. "Un weekend deliberativo all'ombra del Pantheon". Reset, 96, July-August, 2006.

BURnheIM, J. Is democracy possible? The alternative to electoral politics. Berkeley: University of California Press, 1985.

Callenbach, E.; PhIlips, M. A citizen legislature. Berkeley: BanyanTree/Clear Glass, 1985.

CALLON, M.; LASCOUMES, P.; BARTHE, Y. Agir dans un monde incertain. Essai sur la démocratie technique. Paris: Seuil, 2001.

CASTRO, K. D. O júri como instrumento do controle social. Porto Alegre: Sergio Antonio Fabris Editor, 1999.

COHEN, J. Deliberation and democratic legitimacy. In: BoHmAN, J.; ReHG, W. (eds.). Deliberative democracy. Cambridge: MIT Press, 1989. 
COOK, K. J.; POWELL, C. "Unfinished business: aboriginal reconciliation and restorative justice in Australia". Contemporary Justice Review, vol. 6, n³ 3, p. 279-291, 2003.

CouRANT, D. "Pensar el sorteo. Modos de selección, marcos deliberativos y principios democráticos". Daimon: Revista Internacional de Filosofía, n 72, 2017.

CRosby, N. "In search of the competent citizen". Working Paper. Center for New Democratic Processes, Plymouth, 1975.

DAHL, R. Democracy and its critics. New Haven: Yale University Press, 1989.

Del PrÁ, C. G. R. Amicus curiae: instrumento de participação democrática e de aperfeiçoamento da prestação jurisdicional. Curitiba: Juruá Editora, 2007.

DIENEL, P. "Techniken bürgerschaftlicher Beteiligung an Planungsprozessen". Offene Welt, n 101, 1970.

ELSTER, J. Solomonic judgments: studies in the limitation of rationality. Cambridge: Cambridge University Press, 1989.

FEENSTRA, R. "Democracia y elección por sorteo en las nuevas formaciones políticas: teorías políticas clásicas y contemporáneas". Daimon: Revista Internacional de Filosofía, n 72, 2017.

FEYERABEND, P. Against method: outline of an anarchistic theory of knowledge. London: New Left Books, 1975.

FINLEY, M. I. Politics in the ancient world. Cambridge: Cambridge University Press, 1983.

FISHER, R. Grass-roots organizing worldwide: common ground, historical roots, and tension between democracy and the State. In: FISHER, R.; KLING, J. (eds.). Mobilizing the community. Local politics in the era of the global city. Urban Affairs Annual Review, $\mathrm{n}^{\circ} 41$. Newbury Park/London/New Delhi: Sage Publications, 1993.

FISHKIN, J. S. Democracy and deliberation. New directions for democratic reform. New Haven: Yale University Press, 1991.

- Quando o povo fala: democracia deliberativa e consulta pública. Curitiba: Atuação, 2015.

FouCAULT, M. As palavras e as coisas: uma arqueologia das ciências humanas. São Paulo: Martins Fontes, 1981.

FRASER, N. "Rethinking the public sphere: a contribution to the critique of actually existing democracy". Social Text, n²5-26, p. 56-80, 1990.

. Scales of justice. Reimagining political space in a globalizing world. New York: Columbia University Press, 2009.

FROMENTIN, T.; Wolcik, S. (eds.). Le profane en politique: compétences et engagement du citoyen. Paris: L'Harmattan, 2008.

FUNG, A. "Survey article: recipes for public choices spheres: eight institutional design choices and their consequences". The Journal of Political Philosophy, vol. 11, n 3, p. 338-367, 2003.

Goodin, R. E.; DRYZEK, J. S. "Deliberative impacts: the macro-political uptake of mini-publics". Politics \& Society, vol. 34, n², p. 219-244, 2006.

Goodwin, B. Justice by lottery. Chicago: The University of Chicago Press, 1992. 
Guicciardini, F. Dialogue on the government of Florence. Cambridge: Cambridge University Press, 1994.

HÄBERLE, P. Hermenêutica constitucional: a sociedade aberta dos intérpretes da Constituição: contribuição para a interpretação pluralista e procedimental da Constituição. Porto Alegre: Sergio Antônio Fabris Editor, 1997.

El estado constitucional. México, DF: Universidad Nacional Autónoma de México, 2003.

HABERMAS, J. Théorie de I'agir communicationnel. Paris: Fayard, 1987.

HAYEK, F. A. Law, legislation and liberty: a new statement of the liberal principles of justice and political economy. London: Routledge, 1993.

HENDRIKS, C. M. Consensus conferences and planning cells. In: GASTIL, J.; LeVINE, P. (eds.). The deliberative democracy handbook. San Francisco: Jossey-Bass, 2005.

JACQUET, V.; REUCHAMPS, M. "Les 'méthodologues' de la démocratie délibérative. Entre activisme citoyen et recherche scientifique au sein du G1000 et du G100". Participations, vol. 16, n 3, p. 4565, 2016.

KUHN, T. S. La structure des révolutions scientifiques. Paris: Champs Flammarion, 1983.

LANDEMORE, H. "Inclusive constitution-making: the Icelandic experiment". The Journal of Political Philosophy, vol. 23, n², p. 166-191, 2015.

LATOUR, B. Science in action: how to follow scientists and engineers through society. Cambridge: Harvard University Press, 1987.

LÓPEZ-RABATEL, L. "Las aportaciones de la arqueología a la historia de la democracia ateniense". Daimon: Revista Internacional de Filosofía, n 72, 2017.

MACKENZIE, M. K.; WARREN, M. E. Two trust-based uses of minipublics in democratic systems. In: MANSBRIDGE, J.; PARKInSON, J. (eds.). Deliberative systems. Deliberative democracy at the large scale. Cambridge: Cambridge University Press, 2012.

MACPherson, C. B. The life and times of liberal democracy. Oxford: Oxford University Press, 1977.

Manin, B. Principes du gouvernement représentatif. Paris: Flammarion, 1996.

MANSBRIDGE, J. On the idea that participation makes better citizens. In: Elkin, S.; SoltAN, K. (eds.). Citizen competence and democratic institutions. Philadelphia: The Pennsylvania University Press, 1999.

MANSBRIDGE, J., et al. A systemic approach to deliberative democracy. In: MANSBRIDGE, J.; PARKINSON, J. (eds.). Deliberative systems. Deliberative democracy at the large scale. Cambridge: Cambridge University Press, 2012.

Maquiavel, N. História de Florença. São Paulo: Musa Editora, 1994.

MaronA, M. C.; RochA, M. M. "As audiências públicas do Supremo Tribunal Federal: ampliando sua legitimidade democrática?". Revista Teoria e Sociedade, vol. 22, n 1, p. 53-86, 2014.

MeRKLE, D. M. "The polls-review: the national issues convention deliberative poll". Public Opinion Quarterly, vol. 60, no 4, p. 588-619, 1996. 
MICHELS, R. Les partis politiques. Essai sur les tendances oligarchiques de la démocratie. Paris: Payot, 1910.

Miguel, L. F. "Sorteios e representação democrática". Lua Nova, n 50, p. 70-96, 2000.

Moreno Pestaña, J. L. "Sorteo y populismo. El caso de Podemos", Arizona Journal of Hispanic Cultural Studies, n०21, 2017.

NAGEL, J. "Political accountability: combining deliberation and fair representation in community health decisions". University of Pennsylvania Law Review, vol. 140, p. 1.965-1.985, 1992.

PARKInSON, J. Deliberating in the real world. Problems of legitimacy in deliberative democracy. Oxford: Oxford University Press, 2006.

PAteman, C. Participation and democratic theory. London: Cambridge University Press, 1970. "Participatory democracy revisited". Perspectives on Politics, vol. 10, n 1, 7-19, 2012.

Pereira, M. A. G. Modelos democráticos deliberativos e participativos: similitudes, diferenças e desafios. In: DAgnino, E.; TAtAgiBA, L. (orgs.). Democracia, sociedade civil e participação. Chapecó: Argos, 2007.

Pestre, D. Science, argent et politique. Un essai d'interprétation. Paris: Inra Editions, 2001.

PHILLIPS, A. The politics of presence. Oxford: Clarendon Press, 1995.

Quevedo, J. P.; FerreirA, J. H.; InVernizzi, N. "O minipúblico como modelo comunicacional de promoção ao debate sobre riscos da nanotecnologia no Brasil". XVII Congresso de Ciências da Comunicação na Região Sul, Curitiba-PR, 2016.

RaWLS, J. A theory of justice. Cambridge: The Belknap Press of Harvard University Press, 1971.

Rubião, A. Júris de cidadãos. In: AVRITZer, L., et al. (orgs.). Dimensões políticas da justiça. Rio de Janeiro: Civilização Brasileira, 2013.

RUBiÃo, A.; ANVERSA, P. "Sorteio e democracia: a experiência dos júris de cidadãos berlinenses". II Encontro Internacional Participação, Democracia e Políticas Públicas, Unicamp, Campinas-SP, Experiências de participação institucional em perspectiva comparada, 2015.

SAmpaio, R. C. "Minipúblicos on-line: uma metodologia de análise de e-participação pelo desenho institucional". Revista Democracia Digital e Governo Eletrônico, n 6, p. 331-352, 2012.

Schumpeter, J. A. Capitalismo, socialismo e democracia. Rio de Janeiro: Fundo de Cultura, 1961.

SCLOVE, R. E. Democracy and technology. New York: Guilford Press, 1995.

Sintomer, Y. O poder ao povo: júris de cidadãos, sorteio e democracia participativa. Belo Horizonte: Editora UFMG, 2010.

. Petite histoire de l'expérimentation démocratique: tirage au sort et politique d'Athènes à nos jours. Paris: La Découverte, 2011 a.

Démocratie participative, démocratie délibérative: I'histoire contrastée de deux catégories émergentes. In: SINTOMER, Y.; BACQUĖ, M-H. (dir.). La démocratie participative: histoire et généalogie. Paris: La Découverte, 2011b.

. "Sorteo y Política: ¿de la democracia radical a la democracia deliberativa?". Daimon: Revista Internacional de Filosofía, n 72, 2017. 
O SORTEIO NA POLÍTICA: COMO OS MINIPÚBLICOS VÊM TRANSFORMANDO A DEMOCRACIA

SмIтH, G. Democratic innovations. Designing institutions for citizen participation. Cambridge: Cambridge University Press, 2009.

Smith, G.; Wales, C. "'Citizens' juries and deliberative democracy". Political Studies, vol. 48, $\mathrm{n}^{\circ} 1, \mathrm{p}$. 51-65, 2000.

TALPIN, J. Schools of democracy. How ordinary citizens (sometimes) become more competent in participatory budgeting institutions. Colchester: ECPR Press, 2011.

Tocqueville, A. A democracia na América. Belo Horizonte: Itatiaia, 1997.

Thompson, S.; Hoggett, P. "The emotional dynamics of deliberative democracy". Policy and politics, vol. 29, n०3, p. 351-364, 2002.

VAN ReYBrouCK, D. Contra las elecciones: cómo salvar la democracia. Barcelona: Taurus, 2017.

Vergne, A. Le modèle Planungszelle-citizen jury. In: BACQUÉ, M.; SinTOMER, Y. (eds.). Généalogies des dispositifs participatifs contemporains. Paris: Adels/Yves Michel, 2009.

A brief survey of the literature of sortition. Is the age of sortition upon us? In: DELANOI G.; DOWLEN, O. (eds.). Sortition. Theory and practice. Exeter-Charlottesville: Imprint Academic, 2010.

WARren, M. E.; PeARSE, H. (eds.). Designing deliberative democracy: the British Columbia citizens' assembly. Cambridge: Cambridge University Press, 2008.

WRIGHT, E. O. Construyendo utopías reales. Madrid: Akal, 2014.

YIN, R. K. Pesquisa qualitativa do início ao fim. Porto Alegre: Penso, 2016.

Young, I. M. "Representação política, identidade e minorias". Lua Nova, n 67, p. 139-190, 2006.

ZIZEK, S. "The parallax view". New Left Review, n²5, p. 121-134, 2004. 


\section{Abstract}

Sortition in politics: how minipublics are transforming democracy

This article analyzes the use of sortition in politics from a genealogical and contemporary perspective. It aims to reflect on this mechanism, little known in Latin America, which randomly selects citizens to make decisions. The article shows how this idea originated in ancient Greece and was later used in Renaissance Italy, until it was rejected by the modern republics. It shows how selection by lot was rescued in the 1970s amid debates about the crisis of representation and the rise of deliberative democracy, presenting as a novelty the use of the representative sample, as in citizen juries, planning cells, and deliberative opinion polls. The article reveals the dynamics surrounding these minipublics and the field of experimentation that has stemmed from them. It analyzes the criticisms that these mechanisms have received, especially as regards skepticism about the knowledge of ordinary citizens and the fact that random selection prevents the spontaneous participation of society. Recent examples are presented, such as participatory budgeting in Berlin and the Irish constitutional amendment, which provide an empirical basis not only to counter such arguments, but to show that sortition has become a viable alternative in politics.

Keywords: sortition; minipublics; deliberative democracy; social participation; political representation

\section{Resumen}

El sorteo en la política: como los mini-públicos vienen transformando la democracia

Este artículo analiza el uso del sorteo en la política desde una perspectiva genealógica y contemporánea. Visa hacer una reflexión sobre ese mecanismo, poco conocido en América Latina, que selecciona ciudadanos aleatoriamente para tomar decisiones. El artículo muestra como esta idea surgió en la Grecia antigua, fue utilizada en la Italia renacentista, hasta ser rechazada por las repúblicas modernas. Se muestra como el sorteo fue rescatado en los años 70s, junto a los debates sobre la crisis de la representación y el ascenso de la democracia deliberativa, trayendo como novedad la muestra representativa, tal como ocurre en los jurados de ciudadanos, las células de planificación y las encuestas deliberativas. El artículo revela la dinámica en torno a esos mini-públicos y el campo de experimentación que se abrió a partir de ellos. Se hace un análisis de las críticas que esos mecanismos vienen recibiendo, sobre todo el escepticismo en relación al saber-ciudadano y el hecho de que ellos imposibiliten la participación espontánea de la sociedad. Se presentan ejemplos recientes, como el presupuesto participativo berlinés y la enmienda constitucional irlandesa, que proporcionan una base empírica no sólo para contrarrestar estos argumentos, sino para mostrar que el sorteo se ha convertido en una alternativa viable en la política.

Palabras claves: sorteo; mini-públicos; democracia deliberativa; participación social; representación política

\section{Résumé}

Le tirage au sort en politique: comment les mini-publics sont en train de transformer la démocratie

Cet article analyse le tirage au sort en politique d'un point de vue généalogique et contemporain. Ce mécanisme, peu connu en Amérique latine, sélectionne au hasard des citoyens afin de prendre des décisions. L'article explique comment cette idée est née dans la Grèce antique pour ensuite être utilisée en Italie durant la Renaissance, jusqu'à ce qu'elle soit rejetée par les républiques modernes. Il montre comment le tirage au sort a été récupéré dans les années 1970 dans les débats sur la crise de la représentation et la montée de la démocratie délibérative, apportant comme nouveauté, l'échantillon représentatif à l'instar des jurys citoyens, les cellules de planification et les recherches délibératives. L'article révèle la dynamique entourant ces mini-publics et le champ d'expérimentation qui en a découlé. Il analyse les critiques qu'ils ont reçues, surtout par rapport au scepticisme à l'égard du savoir-citoyen et le fait que la sélection aléatoire empêche la participation spontanée de la société. Des exemples récents sont présentés, comme le budget participatif berlinois et l'amendement constitutionnel irlandais, qui fournissent une base empirique non seulement pour contrarier de tels arguments, mais aussi pour montrer que le tirage au sort est devenu une alternative viable en politique.

Mots-clés: tirage au sort; mini-publics; démocratie délibérative; participation sociale; représentation politique

Artigo submetido à publicação em 18 de fevereiro de 2018. Versão final aprovada em 29 de outubro de 2018.

Opinião Pública adota a licença Creative Commons CC-BY. OPINIĀO PUUBLICA

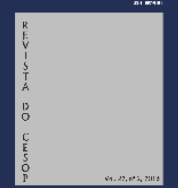

